\title{
On the Shape and Movement of Cirrus Uncinus Clouds by the Trigonometric Method utilizing Stereophotographs Studies of Cirrus Clouds: Part II
}

\author{
By Tsuruhei Yagi, Toshio Harimaya and Choji Magono \\ Department of Geophysics, Hokkaido University, Sapporo \\ (Manuscript received 14 October 1967, in revised form 27 June 1968).
}

\begin{abstract}
Cirrus uncinus clouds were observed by stereophotographs, and were analysed by means of the trigonometric method.

It was confirmed, as a result, that the trail of the cloud had a spatial structure, and that the velocity of the movement of the cap of the cirrus uncinus cloud and the end of its trail coincided with the wind velocity at the respective level. From this fact it was explained that the cloud extended and rotated on a horizontal plane. Namely, the cloud showed the tendency for the trail of the cloud to approach in direction parallel to the prevailing vertical wind shear.
\end{abstract}

\section{Introduction}

The cirrus clouds have generally attracted attention for a long time due to its beauty in shape. However no systematic studies on the shape have been carried out, although the occurrence and the distribution of cirrus clouds were studied up to the present in relation to the synoptic weather condition, that is, to wind, to jet stream, to the transitional layer and so on. Because most of the studies were based on one point observation, a certain assumption was required to decide the height of the cloud observed. Therefore the vertical structure of cirrus clouds could not be considered.

For example, Conover (1960) assumed a vortex motion with the horizontal axis of rotation, in order to interpret the fine streaked structure of a cirrus band. But he did not measure the vertical structure of the clouds to prove his point because of one point observation. Reuss (1963) observed cirrus clouds by means of stereophotogrammetry and confirmed that the direction of clouds at various heights was the same as the vector of the vertical wind shear at the levels concerned. However the trail and the three dimentional fine structure of cirrus clouds were not explained in his paper. The authors (1967) observed cirrus clouds by the trigonometric method with stereophotographs which were taken at oblique angles to the ground surface. The vertical structure of the clouds could not be measured because of difficulties which will be described later, but they confirmed that the velocity of movement of the cirrus clouds coincided with the wind velocity at the level concerned.

Thus, in order to interpret the characteristic shape of cirrus cloud and its movement, it was desirous to pursue successively the three dimentional structure with increasing accurate measurements. Then the authors took successive photographs of cirrus clouds from two points by an improved method, and pursued the time variation in the three dimentional structure of the clouds.

The results of observations of cirrus uncinus clouds on the shape and movement are reported in the present paper.

\section{Observation and Analytical methods}

Several improvements were made in the observation and analysis, although the essential part was the same as in the previous paper (Magono et al. 1967).

\subsection{Improvement in observation}

The length of the base line between two observation points was elongated from 1.72 to 3.883 $\mathrm{km}$, and the direction was changed from W-E to $\mathrm{N}-\mathrm{S}$ to face high clouds, because the base line in the previous observation was too short and 
cirrus clouds mostly appear to the west of Sapporo.

An apparatus to hold a camera was newly designed in such a way as to have an exact rotation around a vertical axis. Two cameras fixed thus were used at two points.

Although it is common practice in the stereoscopic method to set the axes of both cameras parallel to each other, this method was not adopted bacause the exact determination of the direction was impossible due to magnetic disturbance by adjacent buildings. Therefore each camera was aimed at the same cloud and then the azimuth of optical axis of each camera was measured later by a transit, making use of ground features on the principal line of each photograph.

\subsection{Improvement in analysis}

The displacements of identified points on each of pair photographs from the optical axis were measured directly on the photograph and then the azimuth of the point from the optical axis and the elevation of the point from the horizon were calculated, instead of the grid method in the previous work. The elevation angle of the optical axis with respect to the horizon, which was peculiar to the apparatus, was calibrated previously.

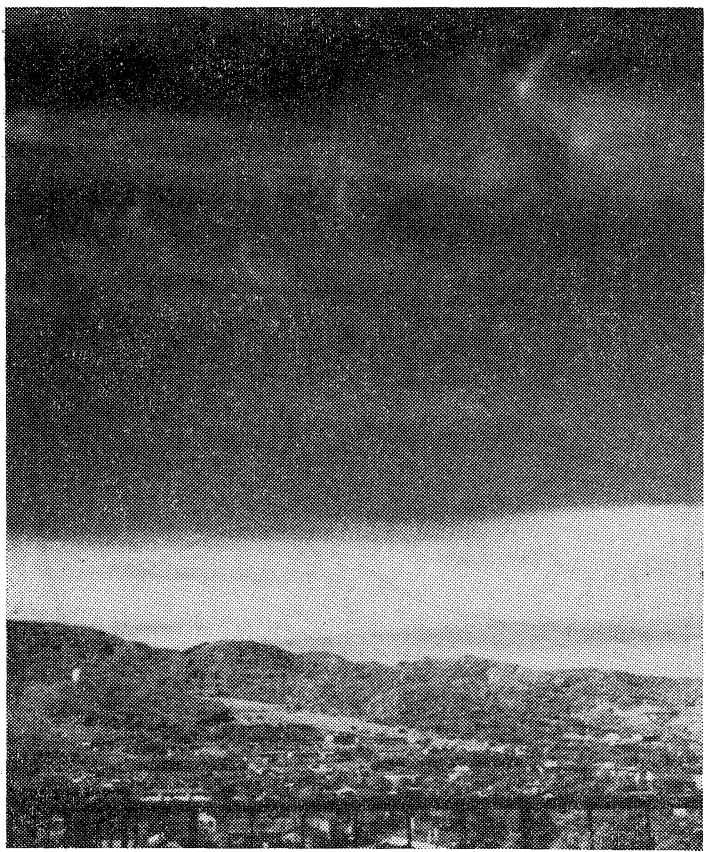

Photo. 1 Left of the pair of cloud photographs at 0945 JST

\section{Observation}

The photographing of cirrus clouds was made around nine o'clock (JST, routine radiosonde time) for three months after August 1965. The observation stations were set up on two buildings of the same height which are located $3,883 \mathrm{~m}$ apart. Walky talkies were used for the confirmation of simultaneous photographing. Two cameras with a facal distance of $3.5 \mathrm{~cm}$ and with a frame size of $2.4 \times 3.5 \mathrm{~cm}$ were used.

The result of the analysis of the cirrus uncinus clouds observed on 27th August are reported in the present paper. Photos. 1 and 2 are a pair of photographs taken at 0945 on this day. The time variations at each five minutes after Photo. 1 are shown in Photos. 3 and 4. These cirrus clouds were moving over the area to the west of Sapporo from NNW to SSE. Each camera was rotated to the left in such a way as to have the same clouds in the center of each frame, as seen in the series of Photos. 1, 3 and 4. Therefore the azimuth of the optical axis of each camera changed with the time. Both axes were not always parallel but were crossed forward. This made it a little inconvenient to view them as stereoscopic photographs, however this was a method neccessary to follow certain moving:

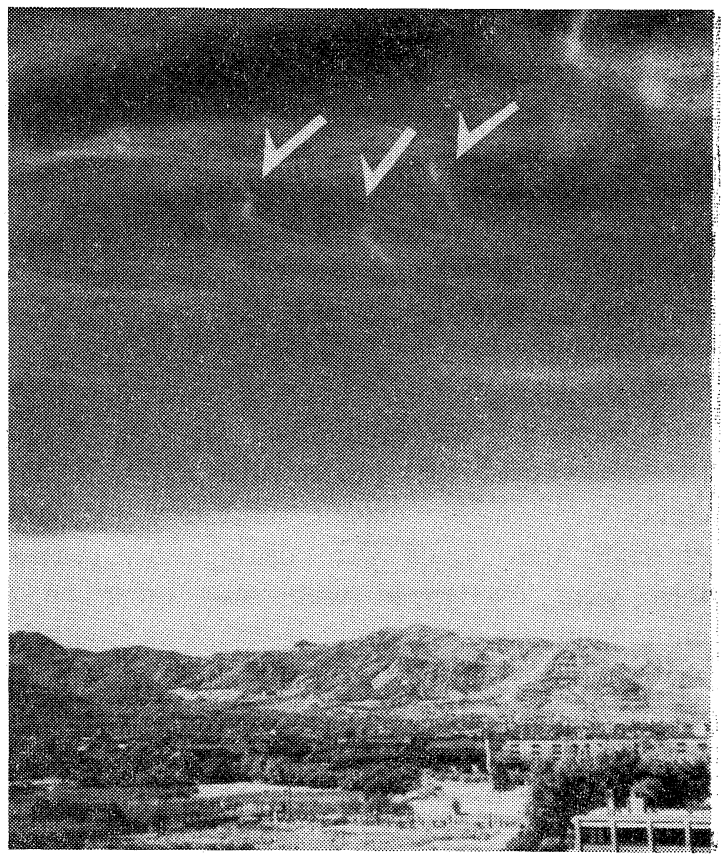

Photo. 2 Right at 0945 


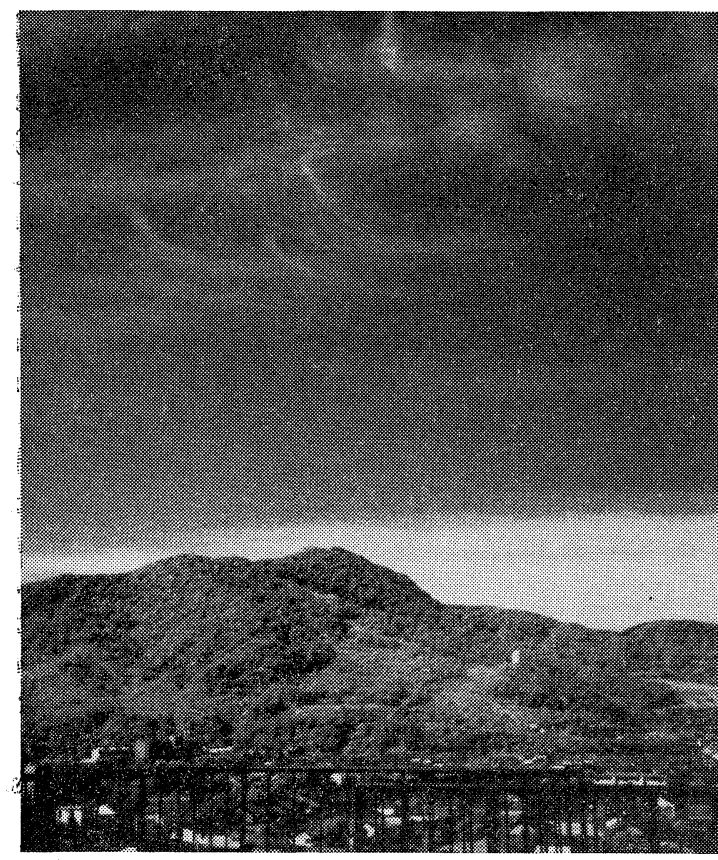

Photo. 3 Left at 0950

cloud.

In the photographs a few kinds of cirrus clouds, especially three cirrus uncimus clouds indicated by arrows near the center are seen. They əxe distributed in an inverted trigon and have a comma-shape with a trail to the right. Comparing the right with the left of a pair of photographs (Photos. 1 and 2) it may be seen that the clouds on the left are apparently steeper than those on the right. In the variation with times in apparent feature, it is noted that their inclination of trails on Photo. 3 became smaller than that on Photo. 1 five minutes before and the trails also grew longer. The same tendencies are seen on Photo. 4 still five minutes later.

These pair photographs were viewed with a stereoscope for the preliminaly analysis. Using the stereoscope, the spatial distribution of the clouds iwere roughly caught on the whole, and especially the clouds were distinguished even if they were overlapped with each other on a photograph. Consequently it was found that the cirrus uncinus clouds in question had a vertical structure and that they were located distinctly further than the banded cirrus clouds.

In the case of quantitative analysis, only identified points of clouds on a pair of photographs were pursued with time, because the trails became dim at the end. Therefore the clouds shown

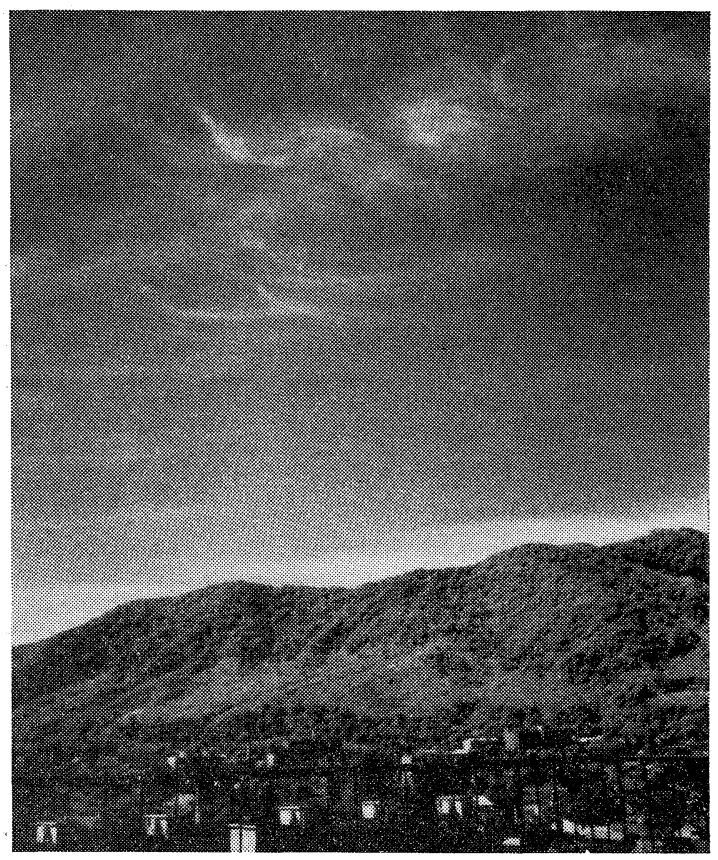

Photo. 4 Left at 0955

in analysed figures are shorter than the actual length.

\section{Results}

Synoptic situations: The surface chart an dthe $300 \mathrm{mb}$ chart at 0900 on the day are shown in Figs. 1 and 2, respectively. In Fig. 2, a subtropical jet stream existed over the north-east of Hokkaido Island. The cirrus clouds were located to the south-west of a bend of the jet stream.

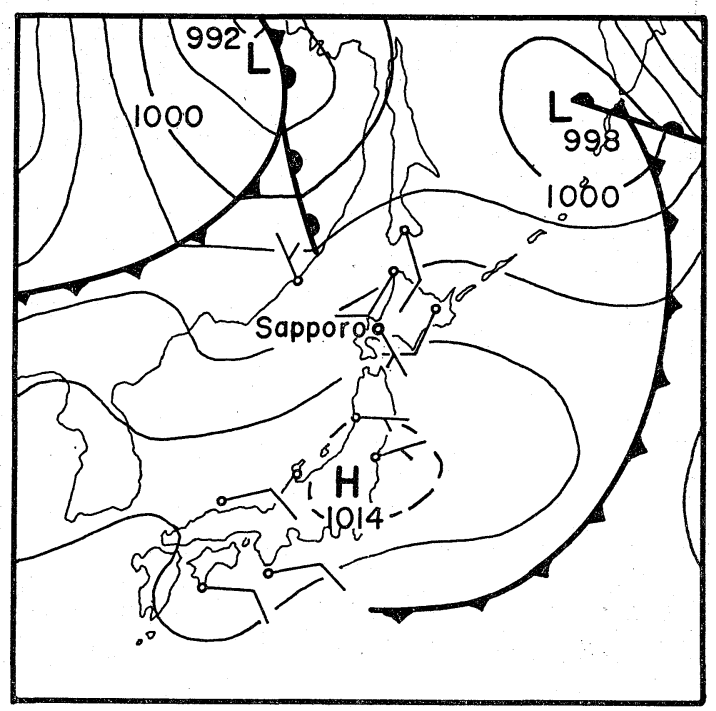

Fig. 1 Surface at 0900, 27 August 1965 


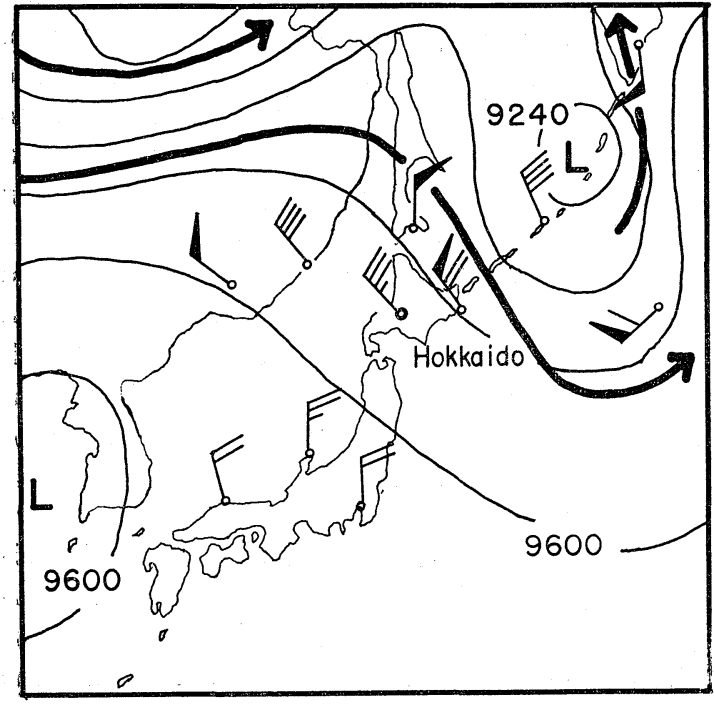

Fig. 2 300mb chart 0900, 27 August 1965

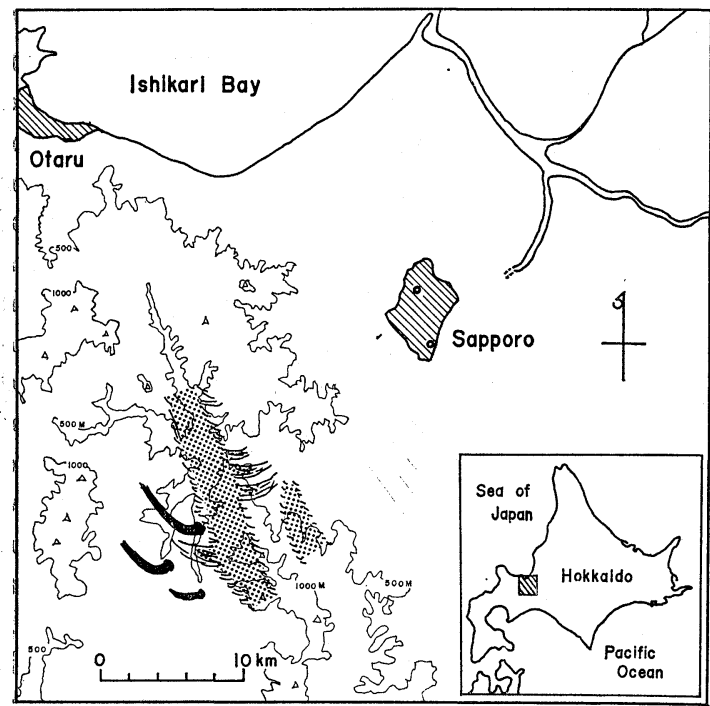

Fig. 3. Horizontal distribution of the cirrus clouds analysed from a pair of photographs at 0950. Circles show the observation sites in Sapporo.

Kadlec (1963) reported that cirrus clouds frequently occurred at such situation. This jet stream may be related to the wind shear which caused the cirrus clouds as described later.

Structure of cirrus uncinus cloud: The horizontal distribution of the cirrus clouds analysed from the pair photographs at 0950 is shown in Fig. 3. Two circles in Sapporo in the figure indicate the locations of the two observation points. The clouds were 20 to $25 \mathrm{~km}$ apart and on the

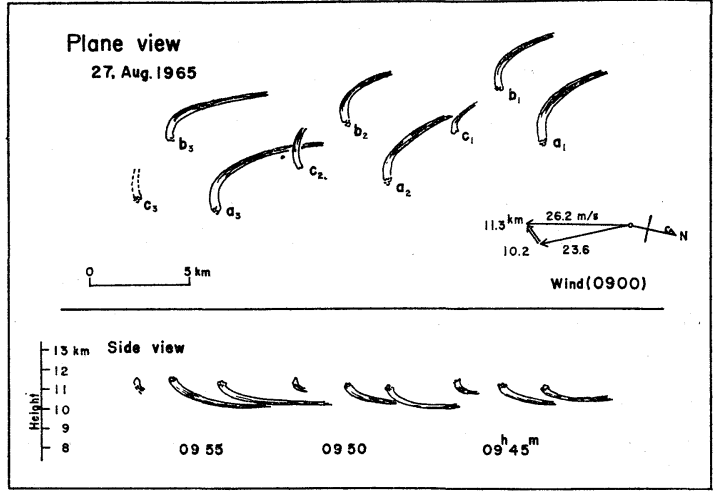

Fig. 4 Movement and transformation of the cirrus uncinus clouds.

Upper: Plane view

Lower: Side view

south-west of the base line. Dotted area shows the distribution of the banded cloud. The noted three uncinus clouds (comma-shape) are distributed to the south-west of the banded cloud. Fig. 4 shows the side and plane views of the three cirrus uncinus clouds and their time variations, which were analysed from Photos. 1, 3 and 4 and their counterparts. The upper part of Fig. 4 is the plane view, and the solid horizontal line shows the direction of the base line. The lower part is the side view corresponding to the plane view looking in a normal direction to the base line. The left vertical axis shows the scale of height, which is common to the horizontal scale.

The wind velocity at the levels of the cap of the cloud and the end of the trail of the cloud are shown in a hodograph on the right hand of Fig. 4. The value of wind speed is shown near the wind vector and the height of each vector is shown near the top of the vector.

Three cirrus uncinus clouds are named as $a, b$. $c$ near each cap. The locations of them at 0945 (Photos. 1 and 2) are referred to as $a_{1}, b_{1}, c_{1}$, at 0950 (Photo. 3) as $a_{2}, b_{2}, c_{2}$ and at 0955 (Photo. 4) as $a_{3}, b_{3}, c_{3}$, respectively.

In the side view of Fig. 4 it is clearly seen that the cloud had a vertical structure of about $1100 \mathrm{~m}$ in depth in such a way that the cap was above and the trail streamed downward. This, while being a matter of course, should be confirmed in such an observation. Incidentally the observational error margin in height was $\pm 200 \mathrm{~m}$. The gradient of the trail was steep near the cap but almost horizontal at its lower part. Since the 
uncinus clouds were also bent on a horizontal plane, it was evident that they took a spiral shape in space. In the plane view it is seen that clouds $a$ and $b$ extended with time as a whole, although the extension shown in the side view is a mere appearance. It is seen also in the horizontal plane that all uncinus clouds moved to the south, and that they rotated clockwise in a steady rate except $c$. The slight irregular deformation of $b_{2}$ and $c_{2}$ might be caused by observational error and the location of $c_{3}$ was not measured because it was behind the other cloud as seen from Photo. 4.

The authors marked the uncinus clouds $a$ and $b$ in the plane view of Fig. 4. In order to survey the motion of the clouds, the wind velocities both at the cap and at the trail end were measured respectively by the relative movement of the portions in Fig. 4. The mean value of moving speed and direction of $a$ and $b$ clouds are shown in Table 1.

\begin{tabular}{c|c|c|c|c}
\hline & \multicolumn{2}{|c|}{ speed } & \multicolumn{2}{c}{ direction } \\
\cline { 2 - 5 } & cloud & wind & cloud & wind \\
\hline $\begin{array}{c}\text { Cap of the cirrus } \\
\text { uncinus cloud } \\
\text { (11.3km height) }\end{array}$ & $\begin{array}{c}27.6 \\
\mathrm{~m} / \mathrm{sec}\end{array}$ & 26.2 & $338^{\circ}$ & 350 \\
\hline $\begin{array}{l}\text { End of the trail } \\
(10.2 \mathrm{~km} \text { height) }\end{array}$ & 24.3 & 23.6 & 336 & 337 \\
\hline
\end{tabular}

Table 1 Mean velocities of the upper and lower ends of the cirrus uncinus clouds, and wind velocities at the respective heights.

The wind speed and direction of corresponding levels were shown also in the table for comparison, which were obtained by radiosonde. It is seen that the speed of the movement of each part of the cloud coincides with the wind speed at the corresponding level within the difference of about $1 \mathrm{~m} / \mathrm{sec}$ and the direction also agrees with a difference of about ten degrees. Considering measurring error, it may be said that this agreement is very well. In other words, both the cap and the end the clouds are transformed by the wind at the respective level.

\section{Consideration}

Generally it is noteworthy in studying a cloud to understand an interaction between the cloud and its environment. Several investigators (Mulkus, 1952; Newton, 1960; Higuchi, 1964) have reported the effects of wind shear on growth and movement of cumulus clouds. It is also necessary to know how high level clouds behave under the wind field. This has scarcely examined up to date. The authors fixed their attention on a cirrus uncinus clouds which had a trail regarded as precipitation from its generator. The trail would be affected and orientated by the wind shear adjacent to the cloud.

It was shown from the above analysis that the cap and the trail end of the cirrus uncinus clouds moved with the same velocity as the wind at each level. From this fact the following considerations were made on the extension and rotation of the clouds as seen in Fig. 4.

Under the field of such a vertical wind shear, the cap and the trail end are transported individually, then the length between them are generally extended. The result of analysis described in Fig. 4 may correspond to this case. From the considerations, the explanation of the thin streaked shape of a cirrus uncinus cloud may be derived.

It is generally considered that, when a cirrus uncinus cloud with vertical extension is formed in a space of certain vertical wind shear, the trail of the cloud is parallel to the wind shear vector, but its direction is in reverse to that of the windshear vector (upper wind vector minus lower wind vector). When the wind shear is changed, the trail approaches a direction parallel to the new wind shear. The rotating of clouds shown in Fig. 4 may be in the course of such a transitional condition, because the cloud direction was different from the wind shear vector at the cloud level. Incidentally the clouds did not form over the observation stations, but come in from the northern sea.

Thus the extension and rotation of the clouds were understood by the present vertical wind shear.

\section{Concluding remarks}

The movement and elongation of cirrus uncinus clouds were explained by the use of prevailing vertical wind shear at the cloud level. However the horizontal component of the commashape of the uncinus cloud could not be explained by the wind data which are shown in Fig. 4. It is considered that such a curved shape of a cloud in horizontal plane depends upon the time change and vertical variation of the vertical wind shear at the cloud level. But the present wind data available were too rough to explain such a detailed 
horizontal comma-shape of the cirrus uncinus cloud. It is desirable to obtain more detail on wind data including those which correspond to the cloud formation time. It is also our hope to follow the movement of the clouds for a longer time.

\section{Acknowledgements}

The authors wish to express their best thanks to the Sapporo Meteorological Observatory and to the Tokyo International Airport Aviation Weather Service for their kindness in offering the aerological data. The expense of this study was defrayed from the Special Fund for Scientific Research of the Education Ministry of Japan.

\section{References}

Conover, J.H., 1960: Cirrus patterns and related air motions near the jet stream as derived by photography. J. Meteor., 17, 532-546.
Higuchi, K., 1965: A three-dimensional study of cumulus clouds by the use of aerial photographs of the clouds and their shadows. J. Atm. Sci., 22, 440447.

Kadlec, P.W., 1963: An in-fright study of the relation between jet streams, cirrus, and wind shear turbulence. U. S. Weather Bureau Contract No. Cwb10356.

Magono, C., T. Harimaya and T. Yagi, 1967: Observation of cirrus clouds by trigonometric method. (-Studies of cirrus clouds: part I-) Geoph. Bull. Hokkaido Univ., 17, 83-98.

Mulkus, J.S., 1952: The slopes of cumulus clouds in relations to external wind shear. Quart. J.R. Meteor. Soc. 78, 530-542.

Newton, C.W., 1960: Hydrodynamic interactions with ambient wind field as a factor in cumulus development. Cumulus Dynamics. New York., Pergamon Press, 135-144.

Reuss, J.H., 1963: Girren in Vertikaler Windsherung. Beit. Phys. Atm., Bd. 36, s. 174-188.

\title{
写真測量により解析されたかぎ状絹雲の形状と運動について (絹雲の研究，その II)
}

\author{
八木 鶴平, 播磨屋敏生, 孫野 長治 \\ (北海道大学地球物理学科, 札幌)
}

1965 年の夏から秋にかけて絹雲の写真観測を行った。札幌市内に約 $3.9 \mathrm{~km}$ 離れた二個所の観測点を設け，時間を追 って同時に絹雲の撮影をして, 三角測量法により解析した。ここでは 8 月 27 日に観測されたかぎ状絹雲の特異な形状 および形状の変化と，雲の高度のほとんど同じ時刻同じ場所の風の資料とを比較し，かぎ状絹雲の運動を考察した。

その結果，かぎ状絹雲は三次元的な構造をもつていて，雲の頭部より滑らかなすじ状の尾流が下降していた. その尾 流の傾きは，頭部の近くでは急だが，下部では注とんど水平であった．

また，かぎ状絹雲の頭部と尾流の末端部の移動速度は，解析された平面図から求めると各々その高度の風の速度と一 致し, 頭部と尾流末端部は各々の高度の風と共に 運動することが確められた。このことから, 観測されたかぎ状絹雲 が，水平面内で全体として時計回りに回転し，またその長さも時間と共にのびていつた事が説明された，すなわち，か ぎ状綟雲は，その高度に拈忷る風の垂直シァーに支配されて，雲の頭部から流れ出ている尾流が，その垂直シァーにな ごんでゆくような傾向で変形しながら，全体としては風と共に移動していった。 